\title{
Anti-EGFR monoclonal antibody $134-\mathrm{mG}_{2 \mathrm{a}}$ exerts antitumor effects in mouse xenograft models of oral squamous cell carcinoma
}

\author{
HIDEKI HOSONO $^{1^{*}}$, JUNKO TAKEI ${ }^{1,2^{*}}$, TOMOKAZU OHISHI ${ }^{3 *}$, MASATO SANO $^{1}$, TEIZO ASANO ${ }^{1}$, \\ YUSUKE SAYAMA $^{1}$, TAKURO NAKAMURA ${ }^{1}$, MIYUKI YANAKA ${ }^{1}$, MANABU KAWADA $^{3}$, \\ HIROYUKI HARADA $^{2}$, MIKA KATO KANEKO ${ }^{1}$ and YUKINARI KATO ${ }^{1,4}$ \\ ${ }^{1}$ Department of Antibody Drug Development, Tohoku University Graduate School of Medicine, Sendai, \\ Miyagi 980-8575; ${ }^{2}$ Department of Oral and Maxillofacial Surgery, Graduate School of Medical and Dental Sciences, \\ Tokyo Medical and Dental University, Tokyo 113-8510; ${ }^{3}$ Institute of Microbial Chemistry (BIKAKEN), \\ Microbial Chemistry Research Foundation, Numazu-shi, Shizuoka 410-0301; \\ ${ }^{4}$ New Industry Creation Hatchery Center, Tohoku University, Sendai, Miyagi 980-8575, Japan
}

Received June 1, 2020; Accepted July 22, 2020

DOI: $10.3892 / \mathrm{ijmm} .2020 .4700$

\begin{abstract}
The epidermal growth factor receptor (EGFR), a transmembrane receptor and member of the human epidermal growth factor receptor (HER) family of receptor tyrosine kinases, is a critical mediator of cell growth and differentiation. EGFR forms homo- or heterodimers with other HER family members to activate downstream signaling cascades in a number of cancer cells. In a previous study, the authors established an anti-EGFR monoclonal antibody (mAb), EMab-134, by immunizing mice with the ectodomain of human EGFR. EMab-134 binds specifically to endogenous EGFR and can be used to detect receptor on oral cancer
\end{abstract}

Correspondence to: Professor Yukinari Kato, New Industry Creation Hatchery Center, Tohoku University, 2-1 Seiryo-machi, Aoba-ku, Sendai, Miyagi 980-8575, Japan

E-mail: yukinarikato@med.tohoku.ac.jp

*Contributed equally

Abbreviations: ADCC, antibody-dependent cellular cytotoxicity; ATCC, American Type Culture Collection; CasMab, cancer-specific monoclonal antibody; CDC, complement-dependent cytotoxicity; CHO, Chinese hamster ovary; DAB, 3,3'-diaminobenzidine tetrahydrochloride; DMEM, Dulbecco's modified Eagle's medium; EDTA, ethylenediaminetetraacetic acid; EGFR, epidermal growth factor receptor; FBS, fetal bovine serum; JCRB, Japanese Collection of Research Bioresources Cell Bank; HER, human epidermal growth factor receptor; $\mathrm{mAb}$, monoclonal antibody; n.s., not significant; OSCC, oral squamous cell carcinoma; PBS, phosphate-buffered saline; PDPN, podoplanin; PODXL, podocalyxin; RPMI, Roswell Park Memorial Institute; PVDF, polyvinylidene difluoride; SEM, standard error of the mean

Key words: EGFR, monoclonal antibody, ADCC, CDC, antitumor activity, oral cancer cell lines by flow cytometry and western blot analysis; this antibody is also effective for the immunohistochemical evaluation of oral cancer tissues. In the present study, the subclass of EMab-134 was converted from $\operatorname{IgG}_{1}$ to $\operatorname{IgG}_{2 \mathrm{a}}\left(134-\mathrm{mG}_{2 \mathrm{a}}\right)$ to facilitate antibody-dependent cellular cytotoxicity (ADCC) and complement-dependent cytotoxicity (CDC). The dissociation constants $\left(K_{\mathrm{D}} \mathrm{s}\right)$ of EMab-134 and $134-\mathrm{mG}_{2 \mathrm{a}}$ against EGFR-expressing CHO-K1 (CHO/EGFR) cells were determined by flow cytometry to be $3.2 \times 10^{-9} \mathrm{M}$ and $2.1 \times 10^{-9} \mathrm{M}$, respectively; these results indicate that $134-\mathrm{mG}_{2 \mathrm{a}}$ has a higher binding affinity than EMab-134. The $134-\mathrm{mG}_{2 \mathrm{a}}$ antibody was more sensitive than EMab-134 with respect to antigen detection in oral cancer cells in both western blot analysis and immunohistochemistry applications. Analysis in vitro revealed that $134-\mathrm{mG}_{2 \mathrm{a}}$ contributed to high levels of ADCC and CDC in experiments targeting $\mathrm{CHO} / \mathrm{EGFR}$, HSC-2, and SAS cells. Moreover, the in vivo administration of $134-\mathrm{mG}_{2 \mathrm{a}}$ significantly inhibited the development of CHO/EGFR, HSC-2, and SAS mouse xenografts in comparison to the results observed in response to EMab-134. Taken together, the findings of the present study demonstrate that the newly-formulated $134-\mathrm{mG}_{2 \mathrm{a}}$ is useful for detecting EGFR by flow cytometry, western blot analysis and immunohistochemistry. Furthermore, the in vivo results suggested that it may also be useful as part of a therapeutic regimen for patients with EGFR-expressing oral cancer.

\section{Introduction}

More than 350,000 individuals are diagnosed with oral cancer annually, and oral cancer will ultimately prove fatal in almost half of those diagnosed with the disease (1). Of the defined histological types of oral cancer, $>90 \%$ of patients are diagnosed with oral squamous cell carcinoma (OSCC), which typically arises on the lips or within the oral cavity (2). The most effective treatments currently available for OSCC depend on its clinical stage at presentation. Although stage-I and -II OSCCs are treated with surgery or radiotherapy, advanced 
stage-III and -IV disease is treated with a combination of surgery, radiotherapy and chemotherapy (3). Chemotherapeutic regimens typically include cisplatin as a first-line agent; it is often combined with docetaxel or 5 -fluorouracil $(4,5)$. Paclitaxel, methotrexate and carboplatin can be also used in the treatment of OSCCs (6); however, there is only limited information available on the efficacy of molecular targeting drugs and/or antibody-based therapies for OSCC.

The epidermal growth factor receptor (EGFR) is a member of the human epidermal growth factor receptor (HER) family of receptor tyrosine kinases, and is involved in cell growth and differentiation (7-9). EGFR forms homo- or heterodimers with other HER family members, such as HER2 and HER3, and thereby activate downstream signaling cascades. These pathways are frequently dysregulated in malignant diseases, including OSCC, often via the overexpression of EGFR (10). Nimotuzumab is a humanized monoclonal antibody (mAb) directed against the extracellular domain of the EGFR that has been shown to have clinical efficacy in various types of cancer (11). Although nimotuzumab has been approved in 29 countries for use in the treatment of advanced head and neck carcinoma, esophageal cancer, nasopharyngeal carcinoma and pancreatic cancer, only modest success has been achieved with respect to the treatment of recurrent and/or metastatic OSCC (12). Although a number of EGFR-targeted therapies have been used in patients with OSCC, treatment failures due to the low response rates and acquired resistance have been reported (13).

In a previous study by the authors, mice were immunized with purified recombinant EGFR, and successfully produced monoclonal EMab-134 (mouse $\mathrm{IgG}_{1}$, kappa). This antibody detected endogenous EGFR in oral cancers in applications including flow cytometry, western blot analysis and immunohistochemistry (14). For example, when used in immunohistochemical analysis, EMab-134 reacted with its target antigen in 36 of $38(94.7 \%)$ oral cancer specimens. The minimum epitope of EMab-134 was determined to be ${ }_{377}$ RGDSFTHTPP $_{-386}$ (15). Although EMab-134 has proven to be very useful for the detection of EGFR, the mouse $\mathrm{IgG}_{1}$ subclass does not facilitate antibody-dependent cellular cytotoxicity (ADCC) or complement-dependent cytotoxicity (CDC) activities.

To address this issue, in the present study, EMab-134 $\left(\operatorname{IgG}_{1}\right.$ subclass) was converted into $134-\mathrm{mG}_{2 \mathrm{a}}$ of the mouse $\operatorname{IgG}_{2 \mathrm{a}}$ subclass. It was then determined whether $134-\mathrm{mG}_{2 \mathrm{a}}$ exhibits ADCC, CDC, and in vivo antitumor activities against OSCCs.

\section{Materials and methods}

Antibodies. Anti-EGFR mAb EMab-134 (mouse $\operatorname{IgG}_{1}$, kappa) was developed as previously described (14). To generate 134- $\mathrm{mG}_{2 \mathrm{a}}, \mathrm{V}_{\mathrm{H}}$ cDNA of EMab-134 and $\mathrm{C}_{\mathrm{H}}$ mouse $\mathrm{IgG}_{2 \mathrm{a}}$ were subcloned into pCAG-Ble vector, and $\mathrm{V}_{\mathrm{L}}$ and $\mathrm{C}_{\mathrm{L}}$ cDNAs of EMab-134 were subcloned into pCAG-Neo vector (FUJIFILM Wako Pure Chemical Corporation), respectively. Vectors were transfected into ExpiCHO-S cells using the ExpiCHO Expression System (Thermo Fisher Scientific, Inc.). The resulting $\mathrm{mAb}, 134-\mathrm{mG}_{2 \mathrm{a}}$, was purified with Protein G-Sepharose (GE Healthcare Bio-Sciences). Mouse IgG (cat. no. I8765), $\operatorname{IgG}_{1}$ (cat. no. M7894), and
$\mathrm{IgG}_{2 \mathrm{a}}$ (cat. no. M7769) were purchased from Sigma-Aldrich; Merck KGaA.

Cell lines. The CHO-K1 cell line was obtained from the American Type Culture Collection (ATCC). Human EGFRexpressing $\mathrm{CHO}-\mathrm{K} 1$ cells (CHO/EGFR) were previously established by the transfection of pCAG/PA-EGFR-RAP-MAP into CHO-K1 cells using Lipofectamine LTX (Thermo Fisher Scientific, Inc.) (16). The amino acid sequences of each tag were as follows: PA tag (17), 12 amino acids (GVAMPGAEDDVV); RAP tag (18), 12 amino acids (DMVNPGLEDRIE); and MAP tag (19), 12 amino acids (GDGMVPPGIEDK). OSCC cell lines, including HSC-2 (oral cavity) and SAS (tongue) were obtained from the Japanese Collection of Research Bioresources Cell Bank (JCRB). CHO-K1 and CHO/EGFR were cultured in Roswell Park Memorial Institute (RPMI)-1640 medium (Nacalai Tesque, Inc.). The HSC-2 and SAS cells were cultured in Dulbecco's modified Eagle's medium (DMEM; Nacalai Tesque, Inc.). Cell culture medium was supplemented with $10 \%$ heat-inactivated fetal bovine serum (FBS; Thermo Fisher Scientific, Inc.), 100 units $/ \mathrm{ml}$ of penicillin, $100 \mu \mathrm{g} / \mathrm{ml}$ streptomycin, and $0.25 \mu \mathrm{g} / \mathrm{ml}$ amphotericin B (Nacalai Tesque, Inc.). Cells were cultured at $37^{\circ} \mathrm{C}$ in a humidified atmosphere containing $5 \% \mathrm{CO}_{2}$.

Animals. All animal experiments were performed in accordance with relevant guidelines and regulations to minimize animal suffering and distress in the laboratory. Animal experiments for ADCC and antitumor activity were approved by the Institutional Committee for Experiments of the Institute of Microbial Chemistry (Permit. no. 2019-049 for ADCC assays, 2019-046 for antitumor experiments). Mice were maintained in a pathogen-free environment $\left(23 \pm 2{ }^{\circ} \mathrm{C}, 55 \pm 5 \%\right.$ humidity) on an 11-h light/13-h dark cycle with food and water supplied ad libitum across the experimental period. Mice were monitored for health and weight every 2 or 5 days during the 3 -week period of each experiment. The loss of original body weight to a point $>25 \%$ and/or a maximum tumor size $>3,000 \mathrm{~mm}^{3}$ were identified as humane endpoints for euthanasia. Mice were euthanized by cervical dislocation; death was verified by respiratory and cardiac arrest.

Flow cytometry. Cells were harvested by brief exposure to $0.25 \%$ trypsin $/ 1 \mathrm{mM}$ ethylenediamine tetra acetic acid (EDTA, Nacalai Tesque, Inc.). After washing with $0.1 \%$ bovine serum albumin in phosphate-buffered saline (PBS), cells were treated with $1 \mu \mathrm{g} / \mathrm{ml}$ of anti-EGFR mAbs for $30 \mathrm{~min}$ at $4^{\circ} \mathrm{C}$ followed by Alexa Fluor 488-conjugated anti-mouse $\mathrm{IgG}$ at a dilution of 1:1,000 (cat. no. 4408S; Cell Signaling Technology, Inc.) for $30 \mathrm{~min}$ at $4^{\circ} \mathrm{C}$. Fluorescence data were collected using an SA3800 Cell Analyzer (Sony Corp.).

Western blot analyses. Cell pellets were suspended using lysis buffer (1\% Triton X-100 and $50 \mu \mathrm{g} / \mathrm{ml}$ aprotinin in PBS) on ice for $15 \mathrm{~min}$. Following centrifugation (20,630 x g, $15 \mathrm{~min}$, $4^{\circ} \mathrm{C}$ ), cell lysates were boiled in sodium dodecyl sulfate sample buffer (Nacalai Tesque, Inc.). The samples were electrophoresed on 5-20\% polyacrylamide gels (Nacalai Tesque, Inc.) and transferred onto polyvinylidene difluoride (PVDF) membranes (Merck KGaA). After blocking with $4 \%$ skim 
milk (Nacalai Tesque, Inc.) for $1 \mathrm{~h}$, the membranes were incubated with anti-EGFR mAbs or anti- $\beta$-actin $(1 \mu \mathrm{g} / \mathrm{ml})$ for $1 \mathrm{~h}$, followed by incubation with HRP-conjugated anti-mouse immunoglobulins at a 1:2,000 dilution (Agilent Technologies, Inc.) for $1 \mathrm{~h}$. The membranes were developed with the ImmunoStar LD Chemiluminescence Reagent (FUJIFILM Wako Pure Chemical Corporation) using the Sayaca-Imager (DRC Co., Ltd.). All western blot analysis procedures were performed at room temperature.

Immunohistochemical analyses. Histological sections (4- $\mu$ m-thick) of an oral cancer tissue array (cat. no. OR601c; US Biomax, Inc.) were directly autoclaved in EnVision FLEX Target Retrieval Solution High pH (Agilent Technologies, Inc.) for $20 \mathrm{~min}$. The sections were then incubated with $5 \mu \mathrm{g} / \mathrm{ml}$ anti-EGFR mAbs for $1 \mathrm{~h}$ at room temperature and treated using an Envision+ kit (Agilent Technologies, Inc.) for $30 \mathrm{~min}$. Color was developed using 3,3'-diaminobenzidine tetrahydrochloride (DAB; Agilent Technologies, Inc.) for $2 \mathrm{~min}$, and the sections were then counterstained with hematoxylin (FUJIFILM Wako Pure Chemical Corporation). Hematoxylin and eosin (H\&E) staining was performed using consecutive tissue sections as follows: Hematoxylin staining (FUJIFILM Wako Pure Chemical Corporation) for $5 \mathrm{~min}$ and eosin staining (FUJIFILM Wako Pure Chemical Corporation) for $2 \mathrm{~min}$ at room temperature. Leica DMD108 (Leica Microsystems $\mathrm{GmbH}$ ) was used to examine the sections and obtain images.

Determination of the binding affinity. The cells were suspended in $100 \mu \mathrm{l}$ of serially diluted anti-EGFR mAbs $(0.6-10 \mu \mathrm{g} / \mathrm{ml})$ followed by the addition of Alexa Fluor 488-conjugated anti-mouse IgG (1:1,000; Cell Signaling Technology, Inc.). Fluorescence data were collected using an EC800 Cell Analyzer (Sony Corp.). The dissociation constant $\left(K_{\mathrm{D}}\right)$ was calculated by fitting binding isotherms to built-in one-site binding models in GraphPad Prism 7 (GraphPad Software, Inc.).

$A D C C$. A total of 6 female 6 -week-old BALB/c nude mice (weighing 15-18 g) were purchased from Charles River Laboratories, Inc. Spleen cells from 6 mice were used as the source of natural killer (NK) cells for the evaluation of ADCC, which has been reported previously (20). Following euthanasia by cervical dislocation, the spleens were removed aseptically and single-cell suspensions were obtained by forcing spleen tissues through a sterile cell strainer (352360, BD Falcon, Corning, Inc.) using a syringe. Erythrocytes were lysed with a 10-sec exposure to ice-cold distilled water. Splenocytes were washed with DMEM and resuspended in DMEM with $10 \%$ FBS; this preparation was used as effector cells. Target tumor cells were labeled with $10 \mu \mathrm{g} / \mathrm{ml}$ Calcein AM (Thermo Fisher Scientific, Inc.) and resuspended in the same medium. The target cells $\left(2 \times 10^{4}\right.$ cells/well) were plated in 96 -well plates and mixed with effector cells (effector/target cell ratio, 50), $100 \mu \mathrm{g} / \mathrm{ml}$ of anti-EGFR antibodies or control IgGs. Following a 4-h incubation at $37^{\circ} \mathrm{C}$, the release of Calcein AM into the supernatant was measured in each well. The fluorescence intensity was determined using a microplate reader (Power Scan HT; BioTek Instruments, Inc.) with an excitation wavelength of $485 \mathrm{~nm}$ and an emission wavelength of $538 \mathrm{~nm}$.
Cytolytic activity (\% lysis) was calculated using the equation $\%$ lysis $=(\mathrm{E}-\mathrm{S}) /(\mathrm{M}-\mathrm{S}) \times 100$, where ' $\mathrm{E}$ ' is the fluorescence measured in combined cultures of target and effector cells, ' $\mathrm{S}$ ' is the spontaneous fluorescence of target cells only, and ' $M$ ' is the maximum fluorescence measured following the lysis of all cells with a buffer containing $0.5 \%$ Triton X-100, $10 \mathrm{mM}$ Tris- $\mathrm{HCl}(\mathrm{pH} 7.4)$ and $10 \mathrm{mM}$ of EDTA.

$C D C$. The cells $\left(2 \times 10^{4}\right.$ cells/well $)$ were plated in 96-well plates and mixed with rabbit complement (final dilution 1:10; Low-Tox-M Rabbit Complement; Cedarlane Laboratories) together with $100 \mu \mathrm{g} / \mathrm{ml}$ of anti-EGFR or control IgGs. Following $5 \mathrm{~h}$ incubation at $37^{\circ} \mathrm{C}$, MTS [3-(4,5-dimethylthiazol-2-yl)-5-(3-carboxymethoxyphenyl)-2-(4-sulfophenyl)$2 \mathrm{H}$-tetrazolium; inner salt] assay was performed using a CellTiter 96 AQueous assay kit (Promega Corp.).

Antitumor activity of 134- $\mathrm{mG}_{2 a}$ in xenografts of CHO/EGFR cells. A total of 24 female BALB/c nude mice (5 weeks old, weighing 14-17 g) were purchased from Charles River Laboratories, Inc. and used in experiments once they reached 7 weeks of age. $\mathrm{CHO} / \mathrm{EGFR}$ cells $\left(0.3 \mathrm{ml}\right.$ of $1.33 \times 10^{8}$ cells $/ \mathrm{ml}$ in DMEM) were mixed with $0.5 \mathrm{ml}$ BD Matrigel Matrix Growth Factor Reduced (BD Biosciences); $100 \mu 1$ of this suspension $\left(5 \times 10^{6}\right.$ cells) was injected subcutaneously into the left flanks of the mice. On day 1 post-inoculation, $100 \mu \mathrm{g}$ of EMab-134 $(\mathrm{n}=8), 134-\mathrm{mG}_{2 \mathrm{a}}(\mathrm{n}=8)$, or control mouse $\operatorname{IgG}(\mathrm{n}=8)$ in $100 \mu \mathrm{l}$ PBS were injected intraperitoneally. Additional antibody inoculations were performed on days 7 and 14. At 21 days following cell implantation, all mice were euthanized by cervical dislocation; tumor diameters and volumes were determined as previously described (21).

Antitumor activity of 134- $m G_{2 a}$ in xenografts of oral cancers. A total of 48 female BALB/c nude mice (5 weeks old, weighing 14-17 g) were purchased from Charles River Laboratories, Inc. and used in experiments once they reached 7 weeks of age. The HSC- 2 and SAS cells $\left(0.3 \mathrm{ml}\right.$ of $1.33 \times 10^{8}$ cells $/ \mathrm{ml}$ in DMEM) were mixed with $0.5 \mathrm{ml}$ BD Matrigel Matrix Growth Factor Reduced (BD Biosciences); $100 \mu 1$ of this suspension ( $5 \times 10^{6}$ cells) was injected subcutaneously into the left flanks of the mice. On day 1 post-inoculation, $100 \mu \mathrm{g}$ of EMab-134 ( $\mathrm{n}=8$ in each group), 134- $\mathrm{mG}_{2 \mathrm{a}}$ ( $\mathrm{n}=8$ in each group), or control mouse $\operatorname{IgG}$ ( $\mathrm{n}=8$ in each group) in $100 \mu \mathrm{l}$ PBS were injected intraperitoneally. Additional antibody inoculations were performed on days 7 and 14. At 18 days following cell implantation, all mice were euthanized by cervical dislocation, and tumor diameters and volumes were determined.

Statistical analyses. All data are expressed as the means \pm standard error of the mean (SEM). Statistical analysis was performed using one-way ANOVA followed by Tukey-Kramer's test using $\mathrm{R}$ statistical ( $\mathrm{R}$ Foundation for Statistical Computing). A value of $\mathrm{P}<0.05$ was adopted as a level of statistical significance.

\section{Results}

Generation and characterization of 134- $m G_{2 a}$, a mouse $I_{g} G_{2 a}$-type anti-EGFR antibody. As mouse $\operatorname{IgG}_{2 \mathrm{a}}$ subclass 
facilitates both ADCC and CDC (22), in the present study, a mouse $\operatorname{IgG}_{2 \mathrm{a}}$ version of the $\mathrm{IgG}_{1}$ EMab-134 (14) was generated by subcloning $\mathrm{V}_{\mathrm{H}}$ cDNA of EMab-134 and $\mathrm{C}_{\mathrm{H}}$ mouse $\mathrm{IgG}_{2 \mathrm{a}}$ into pCAG-Ble vector, and $\mathrm{V}_{\mathrm{L}}$ and $\mathrm{C}_{\mathrm{L}}$ cDNAs of EMab-134 into pCAG-Neo vector. The $\operatorname{IgG}_{2 \mathrm{a}}$ version of EMab-134 was named $134-\mathrm{mG}_{2 \mathrm{a}}$. The sensitivity of $134-\mathrm{mG}_{2 \mathrm{a}}$ in CHO/EGFR, HSC-2 and SAS cells was analyzed by flow cytometry. As shown in Fig. 1, EMab-134 and 134- $\mathrm{mG}_{2 \mathrm{a}}$ were equally effective at detecting $\mathrm{CHO} / \mathrm{EGFR}$, HSC-2 and SAS cells using this method.

Subsequently, the sensitivities of EMab-134 and $134-\mathrm{mG}_{2 \mathrm{a}}$ were compared when used to probe lysates of CHO/EGFR, HSC-2 and SAS cells by western blot analysis. Notably, $134-\mathrm{mG}_{2 \mathrm{a}}$ exhibited a relatively higher reactivity when detecting their targets in cell lysates from CHO/EGFR and HSC-2 cells; both antibodies were faintly reactive against targets in SAS cell lysates (Fig. 2). The molecular weight of the EGFRs of HSC-2 and SAS cells was smaller than that expressed in CHO-K1 cells, as PA-EGFR-RAP-MAP, in which 3 peptide tags, such as PA tag, RAP tag, and MAP tag were added, was transfected into the $\mathrm{CHO}-\mathrm{K} 1$ cells (16).

Immunohistochemical analysis revealed that both EMab-134 and 134- $\mathrm{mG}_{2 \mathrm{a}}$ detected membrane antigens in oral cancer tissues (Fig. 3). 134- $\mathrm{mG}_{2 \mathrm{a}}$ exhibited higher staining intensities when compared to the results from EMab-134 in several oral cancer tissues with various levels of EGFR expression; intensities included 1+ (Fig. 3A), 2+ (Fig. 3B) and 3+ (Fig. 3C). No staining was observed in tissues incubated with the buffer control.

A kinetic analysis of the interactions of EMab-134 and 134- $\mathrm{mG}_{2 \mathrm{a}}$ with $\mathrm{CHO} / \mathrm{EGFR}$ cells was then performed using flow cytometry. As shown in Fig. 4, the dissociation constant $\left(K_{\mathrm{D}}\right)$ for the interaction of EMab-134 with CHO/EGFR cells was $3.2 \times 10^{-9} \mathrm{M}$. By contrast, the $K_{\mathrm{D}}$ for the interaction of 134- $\mathrm{mG}_{2 \mathrm{a}}$ with $\mathrm{CHO} / \mathrm{EGFR}$ cells was $2.1 \times 10^{-9} \mathrm{M}$ (Fig. 4). The binding affinity of $134-\mathrm{mG}_{2 \mathrm{a}}$ for $\mathrm{CHO} / \mathrm{EGFR}$ cells was 1.5 -fold higher than that of EMab-134; taken together with the results from western blot analysis, this result suggests that the higher binding affinity of $134-\mathrm{mG}_{2 \mathrm{a}}$ may result in the higher sensitivity observed in western blot and immunohistochemical analyses.

134- $m G_{2 a}$-mediated ADCC in oral cancer cell lines. Subsequently, whether the newly-developed $134-\mathrm{mG}_{2 \mathrm{a}}$ was capable of mediating ADCC against CHO/EGFR cells or oral cancer cell lines, including HSC-2 and SAS cells was examined. As shown in Fig. 5A, 134- $\mathrm{mG}_{2 \mathrm{a}}$ elicited ADCC (66\% cytotoxicity; $\mathrm{P}<0.01$ ) against $\mathrm{CHO} / \mathrm{EGFR}$ cells more effectively than did control mouse $\operatorname{IgG}_{2 \mathrm{a}}$ (23\% cytotoxicity). By contrast, EMab-134 promoted no significant ADCC (23\% cytotoxicity; n.s.) against CHO/EGFR cells compared to that observed in response to control mouse $\operatorname{IgG}_{1}(23 \%$ cytotoxicity). Similarly, $134-\mathrm{mG}_{2 \mathrm{a}}$ elicited ADCC (53\% cytotoxicity; $\left.\mathrm{P}<0.01\right)$ against the HSC-2 cells more effectively than did control mouse $\operatorname{IgG}_{2 \mathrm{a}}$ (13\% cytotoxicity) (Fig. 5B). By contrast, EMab-134 elicited no significant ADCC (14\% cytotoxicity; n.s.) against the HSC-2 cells compared to that observed in response to mouse $\mathrm{IgG}_{1}$ control (13\% cytotoxicity). Furthermore, $134-\mathrm{mG}_{2 \mathrm{a}}$ elicited higher ADCC (63\% cytotoxicity; $\mathrm{P}<0.01)$ against the SAS cells compared with that elicited by control mouse $\operatorname{IgG}_{2 \mathrm{a}}(32 \%$ cytotoxicity; Fig. 5C), while EMab-134 elicited no significant
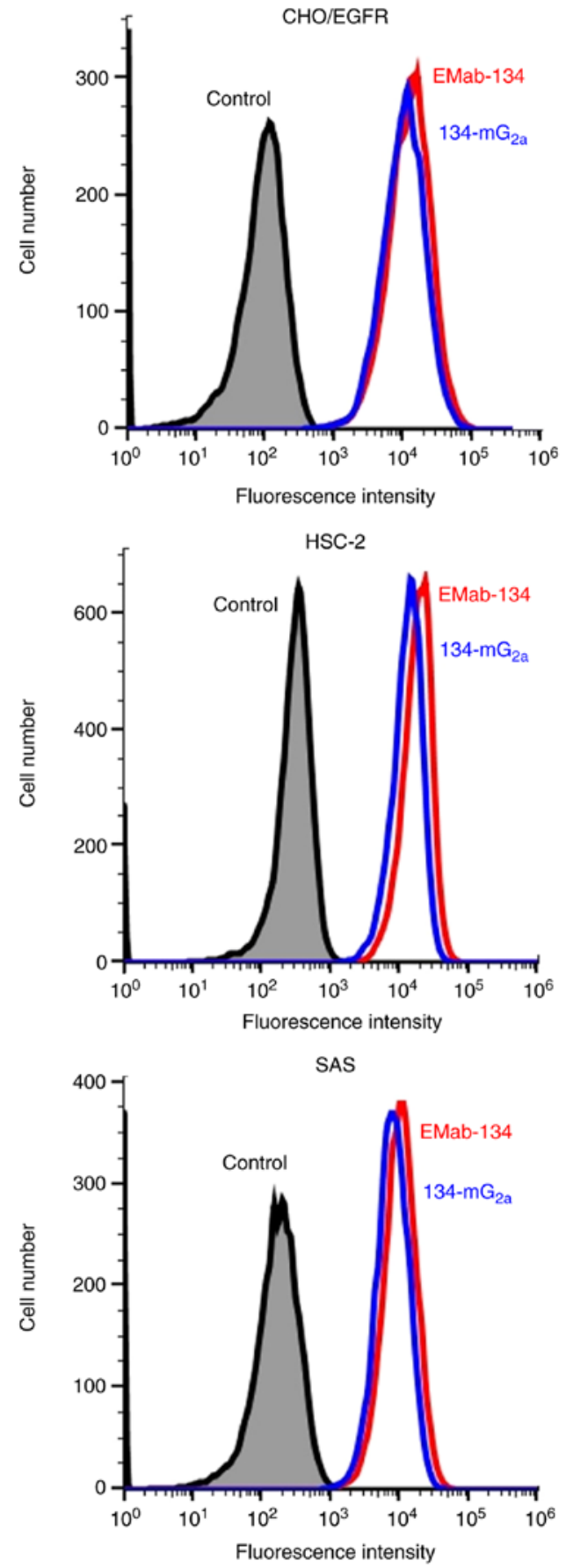

Figure 1. Flow cytometry with anti-EGFR mAbs. EGFR was detected on CHO/EGFR, HSC-2, and SAS cells using EMab-134, 134- $\mathrm{mG}_{2 \mathrm{a}}$, or buffer control, followed by secondary antibodies. Fluorescence data were collected using an SA3800 Cell Analyzer. EGFR, epidermal growth factor receptor; mAbs, monoclonal antibodies.

ADCC ( $32 \%$ cytotoxicity; n.s.) against SAS cells compared to that observed in response to control mouse $\mathrm{IgG}_{1}(33 \%$ cytotoxicity). Taken together, the novel $\mathrm{mAb} 134-\mathrm{mG}_{2 \mathrm{a}}$ exhibited significantly higher ADCC for all 3 EGFR-expressing cell lines featured in the present study; by contrast, no ADCC was observed in response to EMab-134.

134- $m G_{2 a}$-mediated $C D C$ in oral cancer cell lines. The present study then examined whether $134-\mathrm{mG}_{2 \mathrm{a}}$ induces $\mathrm{CDC}$ in $\mathrm{CHO} / \mathrm{EGFR}$ cells or in oral cancer cell lines, including 

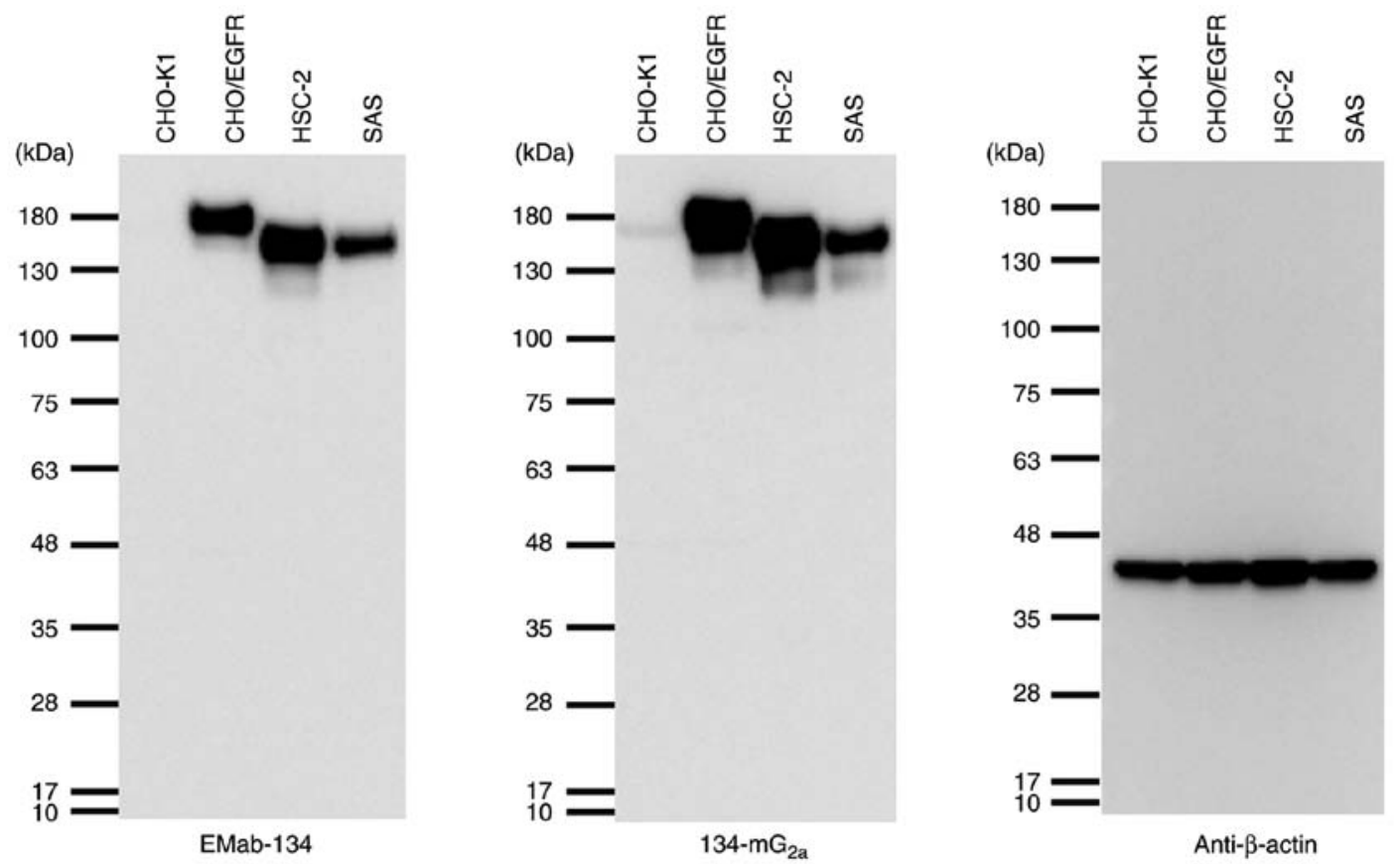

Figure 2. Western blot analysis using anti-EGFR mAbs. Cell lysates of CHO-K1, CHO/EGFR, HSC-2 and SAS cells were subjected to gel electrophoresis and transferred onto PVDF membranes. The membranes were probed with EMab-134, 134- $\mathrm{mG}_{2 \mathrm{a}}$, and anti- $\beta$-actin followed by peroxidase-conjugated anti-mouse immunoglobulins. EGFR, epidermal growth factor receptor; mAbs, monoclonal antibodies.
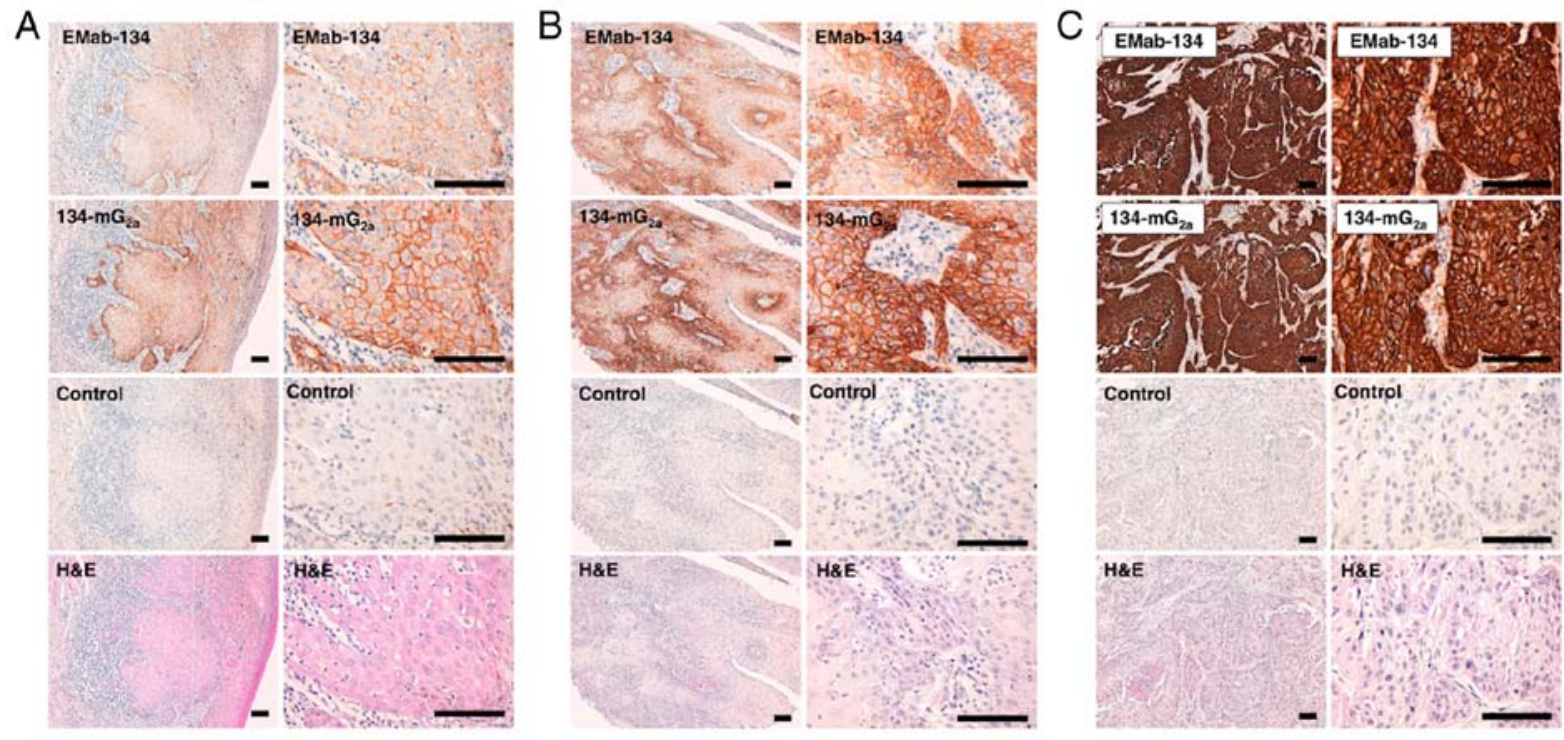

Figure 3. Immunohistochemical analysis of oral cancers with anti-EGFR mAbs. Formalin-fixed paraffin-embedded tissue sections from various oral cancers were probed with EMab-134, 134- $\mathrm{mG}_{2 \mathrm{a}}$, or buffer control, followed by detection using the Envision+ kit; scale bar=100 $\mu \mathrm{m}$. H\&E, hematoxylin and eosin staining. (A) 1+ staining pattern. (B) 2+ staining pattern. (C) 3+ staining pattern. EGFR, epidermal growth factor receptor; mAbs, monoclonal antibodies.

HSC-2 and SAS cells. As shown in Fig. 6A, 134- $\mathrm{mG}_{2 \mathrm{a}}$ elicited a higher degree of $\mathrm{CDC}(46 \%$ cytotoxicity; $\mathrm{P}<0.01)$ in $\mathrm{CHO} / \mathrm{EGFR}$ cells compared with that elicited by control mouse $\operatorname{IgG}_{2 \mathrm{a}}(5.9 \%$ cytotoxicity). By contrast, EMab-134 elicited no significant CDC (11\% cytotoxicity; n.s.) against CHO/EGFR cells compared to that observed in response to control mouse $\mathrm{IgG}_{1}$ (7.4\% cytotoxicity). Similarly, $134-\mathrm{mG}_{2 \mathrm{a}}$ elicited a higher degree of CDC (79\% cytotoxicity; $\mathrm{P}<0.01)$ against $\mathrm{HSC}-2$ cells compared with that elicited by control mouse $\operatorname{IgG}_{2 \mathrm{a}}$ (19\% cytotoxicity; Fig. 6B). By contrast, EMab-134 elicited no significant CDC (20\% cytotoxicity; n.s.) against the HSC-2 cells compared to that observed in response to control mouse $\mathrm{IgG}_{1}\left(19 \%\right.$ cytotoxicity). Furthermore, $134-\mathrm{mG}_{2 \mathrm{a}}$ elicited a higher degree of CDC $(60 \%$ cytotoxicity; $\mathrm{P}<0.01)$ against SAS cells compared with that elicited by control mouse $\operatorname{IgG}_{2 \mathrm{a}}$ (15\% cytotoxicity; Fig. 6C). By contrast, EMab-134 elicited no significant CDC (28\% cytotoxicity; n.s.) against the SAS cells compared to that observed in response to control mouse $\operatorname{IgG}_{1}(20 \%$ cytotoxicity). Taken together, these results demonstrated that $134-\mathrm{mG}_{2 \mathrm{a}}$ promoted significantly higher levels of CDC against all EGFR-expressing cells evaluated in this study; by contrast, EMab-134 was not effective in this role. 

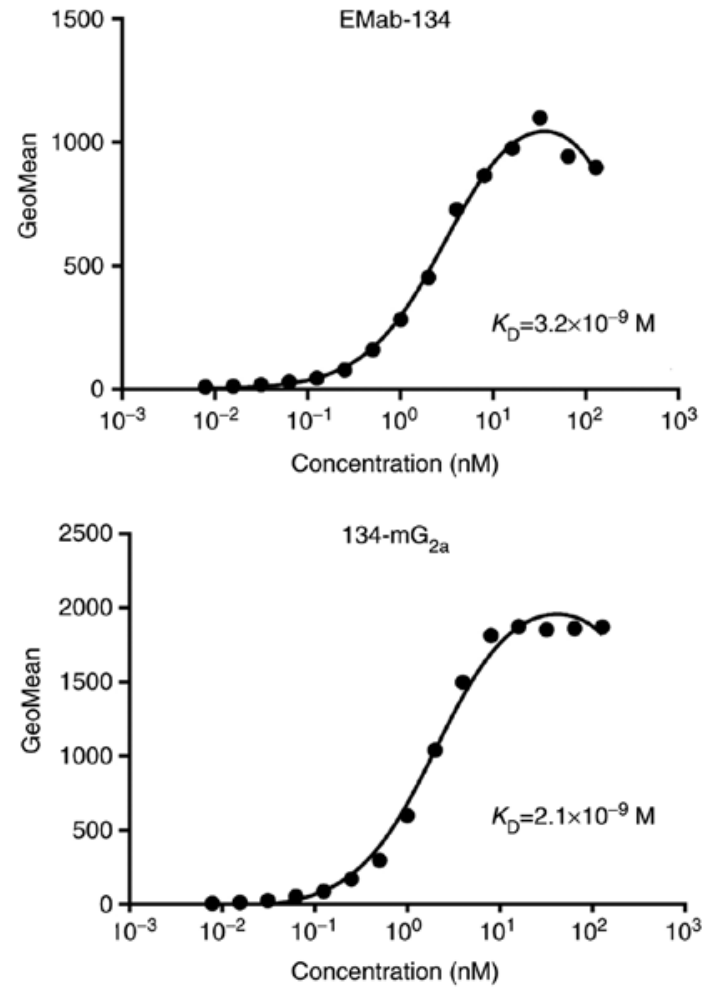

Figure 4. Determination of the binding affinity of anti-EGFR mAbs for targets on CHO/EGFR cells using flow cytometry. CHO/EGFR cells were suspended in $100 \mu 1$ of serially diluted mAbs, followed by the addition of Alexa Fluor 488-conjugated anti-mouse IgG. Fluorescence data were collected using an EC800 Cell Analyzer. EGFR, epidermal growth factor receptor; $\mathrm{mAbs,} \mathrm{monoclonal} \mathrm{antibodies.}$

As the $\mathrm{ADCC} / \mathrm{CDC}$ activities of $134-\mathrm{mG}_{2 \mathrm{a}}$ in oral cancer cells were all potent and effective, this antibody may also exert antitumor activity against oral cancer cells in vivo.

Antitumor activities of 134- $m G_{2 a}$ in the mouse xenografts of $\mathrm{CHO} / \mathrm{EGFR}$ cells. In the CHO/EGFR xenograft models, $134-\mathrm{mG}_{2 \mathrm{a}}(100 \mu \mathrm{g})$, EMab-134 $(100 \mu \mathrm{g})$ and control mouse IgG $(100 \mu \mathrm{g})$ were injected intraperitoneally into the mice on days 1,7 and 14 following the injection of $\mathrm{CHO} / \mathrm{EGFR}$ cells. The tumor volume was measured on days $7,9,14,18$ and 21 after the injection. The administration of $134-\mathrm{mG}_{2 \mathrm{a}}$ resulted in a significant reduction in tumor development on days $7(\mathrm{P}<0.01), 9(\mathrm{P}<0.01), 14(\mathrm{P}<0.05), 18(\mathrm{P}<0.01)$ and 21 $(\mathrm{P}<0.01)$ compared to the mice treated with either EMab-134 or control mouse IgG (Fig. 7). No significant differences in tumor volume were observed in a comparison between the EMab-134- and control IgG-treated mice on days 7, 9, 14, 18 , and 21 . The administration of $134-\mathrm{mG}_{2 \mathrm{a}}$ resulted in a $41 \%$ reduction in tumor volume compared to the EMab-134-treated mice on day 21 post-injection. Furthermore, tumors from the $134-\mathrm{mG}_{2 \mathrm{a}}$-treated mice weighed significantly less than tumors from the EMab-134-treated mice (50\% reduction; $\mathrm{P}<0.01$, Fig. 8A). No significant differences in tumor weights were observed when comparing those from the EMab-134- and control mouse IgG-treated mice (Fig. 8A). Tumors that were resected from mice on day 21 are illustrated in Fig. 8B. Total body weights did not differ significantly among the 3 groups (data not shown). Taken together, these results indicated that
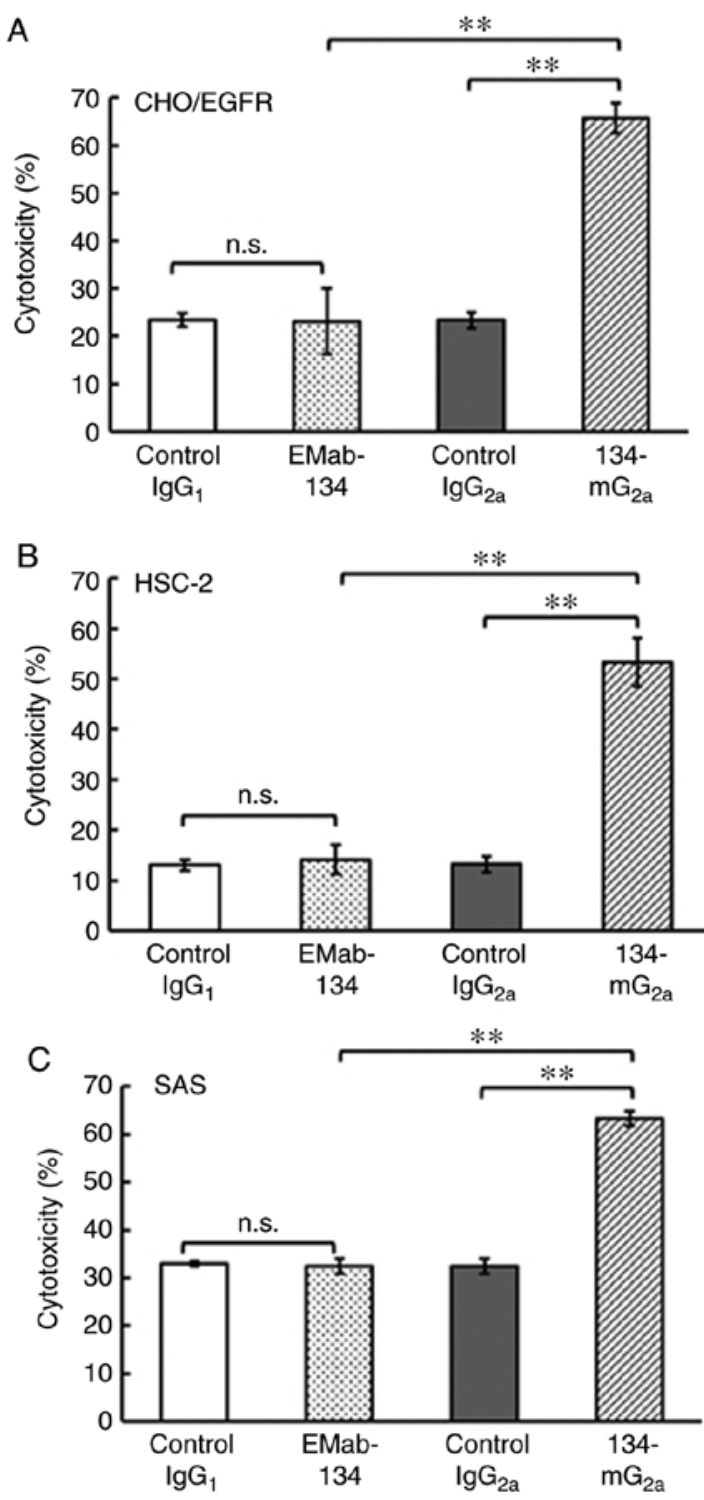

Figure 5. Evaluation of ADCC elicited by anti-EGFR mAbs. (A) ADCC elicited by EMab-134, 134- $\mathrm{mG}_{2 \mathrm{a}}$, control $\mathrm{IgG}_{1}$, or control $\mathrm{IgG}_{2 \mathrm{a}}$ targeting CHO/EGFR cells. (B) ADCC elicited by EMab-134, 134-mG2a, control IgG1, or control $\mathrm{IgG}_{2 \mathrm{a}}$ targeting HSC-2 cells. (C) ADCC elicited by EMab-134, 134- $\mathrm{mG}_{2 \mathrm{a}}$, control $\mathrm{IgG}_{1}$, or control mouse $\mathrm{IgG}_{2 \mathrm{a}}$ targeting SAS cells. Values shown are the means \pm SEM. Asterisks indicate statistical significance $\left({ }^{* *} \mathrm{P}<0.01 ;\right.$ n.s., not significant; one-way ANOVA and Tukey-Kramer's test). ADCC, antibody-dependent cellular cytotoxicity; EGFR, epidermal growth factor receptor; mAbs, monoclonal antibodies.

the administration of 134- $\mathrm{mG}_{2 \mathrm{a}}$ effectively reduced the growth of $\mathrm{CHO} / \mathrm{EGFR}$ xenografts.

Antitumor activities of $134-m G_{2 a}$ in mouse xenografts of HSC-2 oral cancer cells. In the HSC-2 xenograft models, $134-\mathrm{mG}_{2 \mathrm{a}}$ $(100 \mu \mathrm{g})$, EMab-134 $(100 \mu \mathrm{g})$, or control mouse IgG $(100 \mu \mathrm{g})$ were injected intraperitoneally into mice on days 1,7 and 14 after the HSC-2 cell injections. Tumor volume was measured on days $7,9,14$ and 18 . The administration of $134-\mathrm{mG}_{2 \mathrm{a}}$ resulted in significantly decreased tumor development on days $7(\mathrm{P}<0.01)$, $9(\mathrm{P}<0.01), 14(\mathrm{P}<0.01)$ and $18(\mathrm{P}<0.01)$ in comparison to the EMab-134-treated mice (Fig. 9). No significant differences were observed between the EMab-134- and control IgG-treated mice on days 7, 9, 14 and 18 . The administration of $134-\mathrm{mG}_{2 \mathrm{a}}$ 

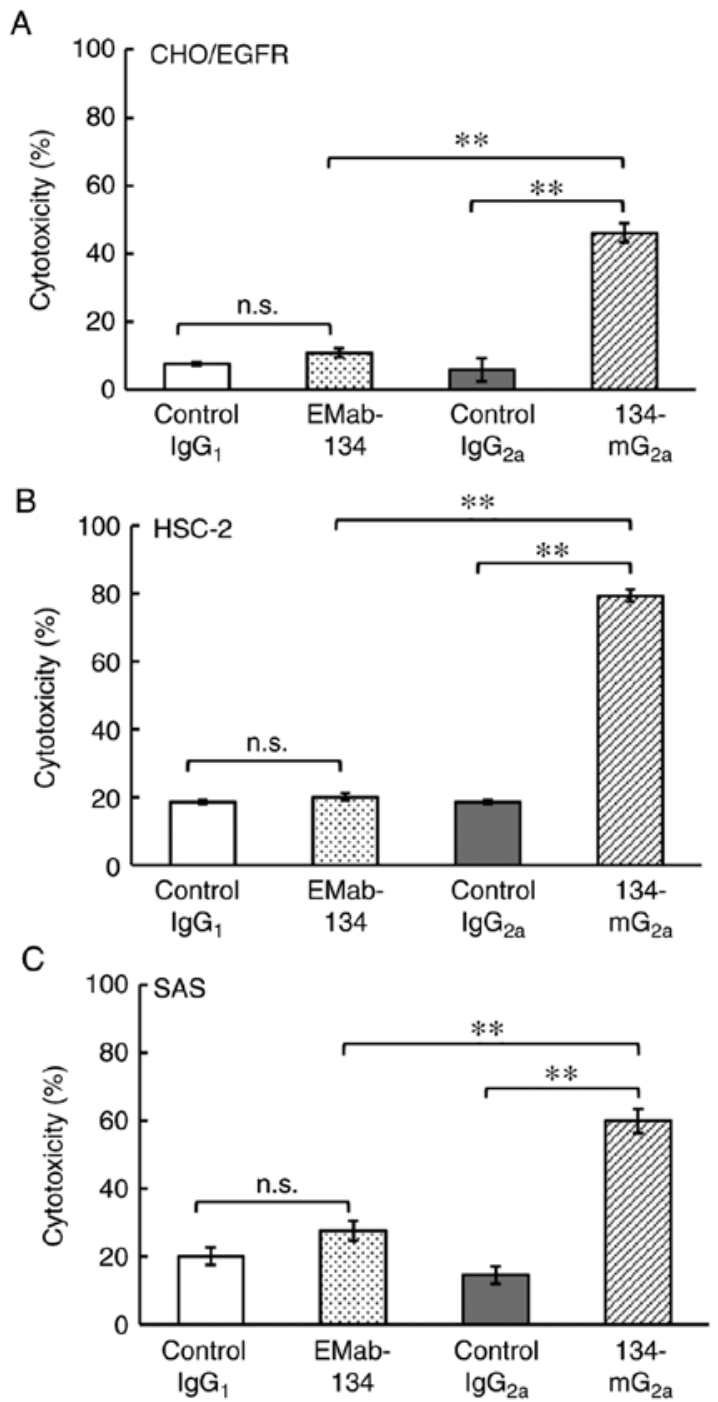

Figure 6. Evaluation of CDC elicited by anti-EGFR mAbs. (A) CDC elicited by EMab-134, 134- $\mathrm{mG}_{2 \mathrm{a}}$, control $\mathrm{IgG}_{1}$, or control $\mathrm{IgG}_{2 \mathrm{a}}$ in target CHO/EGFR cells. (B) CDC elicited by EMab-134, 134- $\mathrm{mG}_{2 \mathrm{a}}$, control $\mathrm{IgG}_{1}$, or control $\mathrm{IgG}_{2 \mathrm{a}}$ in target HSC-2 cells. (C) CDC elicited by EMab-134, 134- $\mathrm{mG}_{22}$, control $\mathrm{IgG}_{1}$, or control $\mathrm{IgG}_{2 \mathrm{a}}$ in target $\mathrm{SAS}$ cells. Values shown are the means $\pm \mathrm{SEM}$. Asterisks indicate statistical significance $\left({ }^{* *} \mathrm{P}<0.01 ;\right.$ n.s. not significant; one-way ANOVA and Tukey-Kramer's test). CDC, complement-dependent cytotoxicity; EGFR, epidermal growth factor receptor; mAbs, monoclonal antibodies.

resulted in a 57\% reduction in tumor volume compared to the EMab-134-treated mice on day 18 post-injection. Tumors from the $134-\mathrm{mG}_{2 \mathrm{a}}$-treated mice weighed significantly less than the tumors from the EMab-134-treated mice (37\% reduction; $\mathrm{P}<0.01$, Fig. 10A). No significant differences in tumor weight were observed when comparing those from the EMab-134- and control mouse IgG-treated mice. Tumors resected on day 18 are illustrated in Fig. 10B. Total body weights did not differ significantly among the 3 groups (data not shown). These results indicated that the administration of $134-\mathrm{mG}_{2 \mathrm{a}}$ effectively limited the growth of HSC-2 cell xenografts.

Antitumor activities of 134- $m G_{2 a}$ in mouse xenografts of SAS oral cancer cells. In the SAS xenograft models, $134-\mathrm{mG}_{2 \mathrm{a}}$ $(100 \mu \mathrm{g})$, EMab-134 $(100 \mu \mathrm{g})$, and control mouse $\operatorname{IgG}(100 \mu \mathrm{g})$ were injected intraperitoneally into the mice on days 1,7 and

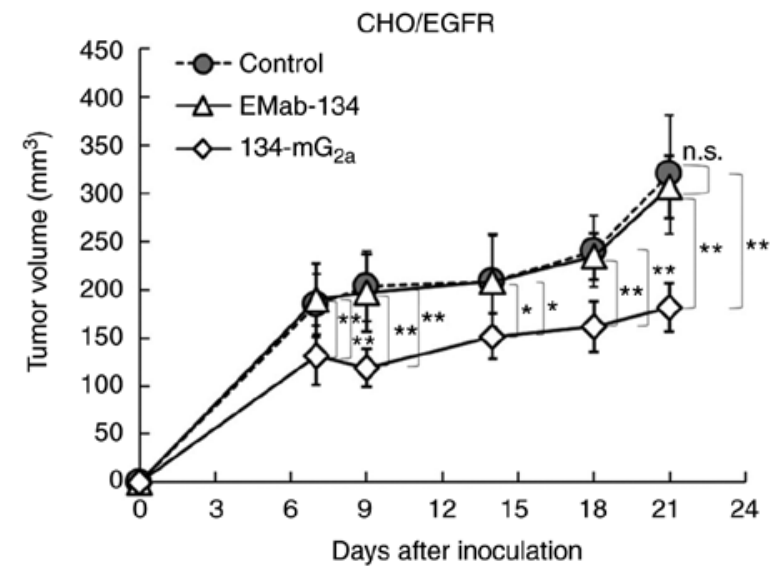

Figure 7. Evaluation of antitumor activity of $134-\mathrm{mG}_{2 \mathrm{a}}$ in $\mathrm{CHO} / \mathrm{EGFR}$ xenografts (tumor size). CHO/EGFR cells $\left(5 \times 10^{6}\right.$ cells) were injected subcutaneously into the left flank. After day $1,100 \mu \mathrm{g}$ of EMab-134, 134- $\mathrm{mG}_{2 \mathrm{a}}$, or control mouse IgG in $100 \mu 1$ PBS were injected intraperitoneally into mice; additional antibodies were then injected on day 7 and day 14. Tumor volume was measured on days 7,9,14, 18 and 21 . Values shown are the means \pm SEM. Asterisks indicate statistical significance $\left({ }^{* *} \mathrm{P}<0.01,{ }^{*} \mathrm{P}<0.05\right.$; n.s., not significant; one-way ANOVA and Tukey-Kramer's test). EGFR, epidermal growth factor receptor; mAbs, monoclonal antibodies.

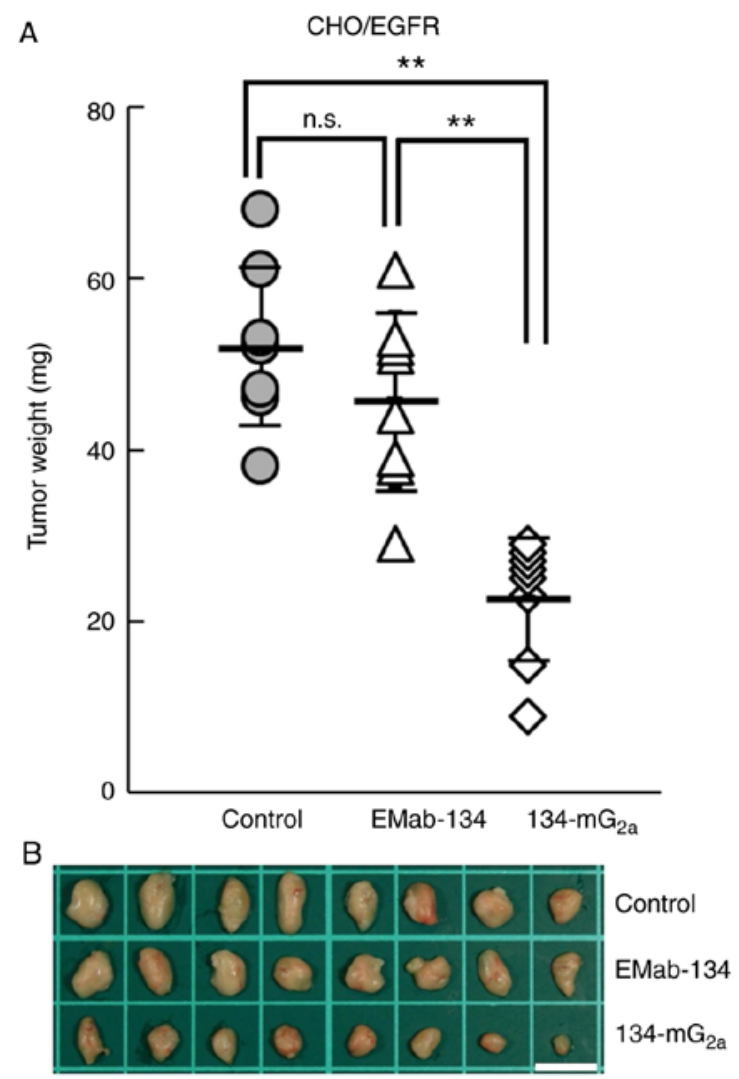

Figure 8. Evaluation of antitumor activity of $134-\mathrm{mG}_{2 \mathrm{a}}$ in $\mathrm{CHO} / \mathrm{EGFR}$ xenografts (tumor weight). (A) Xenograft tumors were resected from each mouse on day 21; tumor weights were determined. Values shown are the means \pm SEM. Asterisks indicate statistical significance $\left({ }^{* *} \mathrm{P}<0.01\right.$; n.s., not significant; one-way ANOVA and Tukey-Kramer's test). (B) Resected tumors of CHO/EGFR xenografts from each group on day 21. Scale bar, $1 \mathrm{~cm}$. EGFR, epidermal growth factor receptor.

14 after SAS cell injections. Tumor volumes were measured on days $7,9,14$ and 18 . The administration of $134-\mathrm{mG}_{2 \mathrm{a}}$ resulted 


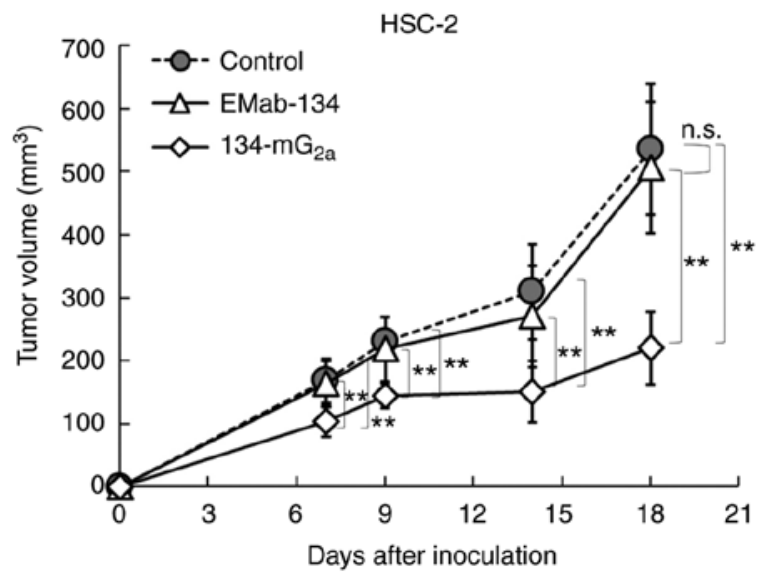

Figure 9. Evaluation of antitumor activity of $134-\mathrm{mG}_{2 \mathrm{a}}$ in $\mathrm{HSC}-2$ xenografts (tumor size). HSC-2 $\left(5 \times 10^{6}\right.$ cells) were injected subcutaneously into the left flanks of the mice. After day 1, $100 \mu \mathrm{g}$ of EMab-134, 134- $\mathrm{mG}_{2 \mathrm{a}}$, or control mouse IgG in $100 \mu 1$ PBS were injected intraperitoneally into the mice. Additional antibodies were then injected on days 7 and 14. Tumor volume was measured on days 7,9,14 and 18 . Values shown are the means \pm SEM. Asterisks indicate statistical significance ${ }^{* *} \mathrm{P}<0.01$; n.s., not significant; one-way ANOVA and Tukey-Kramer's test).

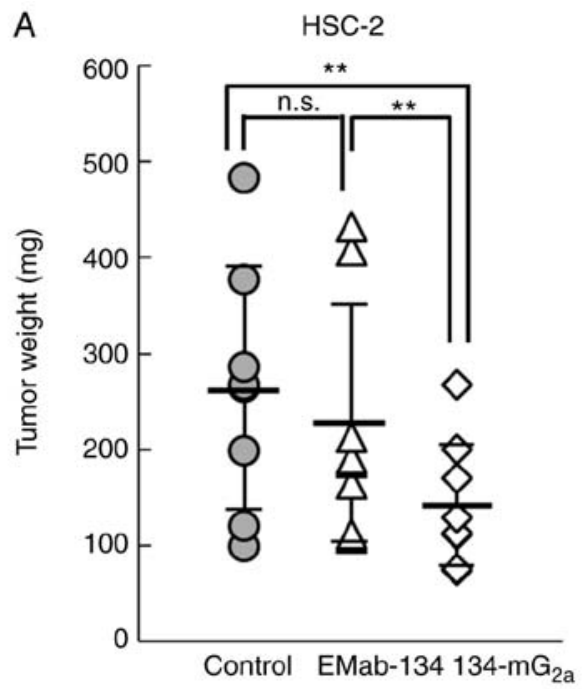

B

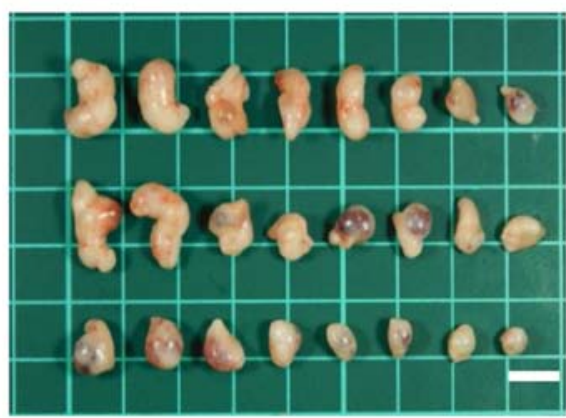

Control

EMab-134

$134-\mathrm{mG}_{2 \mathrm{a}}$

Figure 10. Evaluation of antitumor activity of $134-\mathrm{mG}_{2 \mathrm{a}}$ in $\mathrm{HSC}-2$ xenografts (tumor weight). (A) Xenograft tumors were resected from each mouse on day 18; tumor weights were determined. Values shown are the means \pm SEM. Asterisks indicate statistical significance $\left({ }^{* *} \mathrm{P}<0.01\right.$; n.s., not significant; one-way ANOVA and Tukey-Kramer's test). (B) Resected tumors of HSC-2 xenografts from each group on day 18 . Scale bar, $1 \mathrm{~cm}$.

in significantly reduced tumor development as determined on days $7(\mathrm{P}<0.01), 9(\mathrm{P}<0.01), 14(\mathrm{P}<0.01)$ and $18(\mathrm{P}<0.01)$

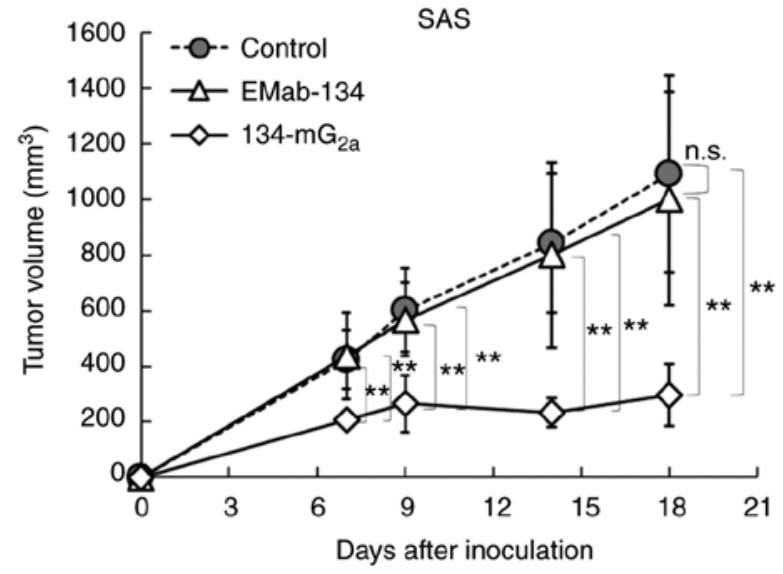

Figure 11. Evaluation of antitumor activity of $134-\mathrm{mG}_{2 \mathrm{a}}$ in SAS xenografts (tumor size). SAS $\left(5 \times 10^{6}\right.$ cells) were injected subcutaneously into the left flanks of the mice. After day 1, $100 \mu \mathrm{g}$ of EMab-134, 134- $\mathrm{mG}_{2 \mathrm{a}}$, or control mouse IgG in $100 \mu \mathrm{l}$ PBS were injected intraperitoneally into the mice. Additional antibodies were injected on days 7 and 14. Tumor volume was measured on days 7, 9, 14 and 18. Values shown are the means \pm SEM. Asterisks indicate statistical significance $\left({ }^{* *} \mathrm{P}<0.01\right.$; n.s., not significant; one-way ANOVA and Tukey-Kramer's test).

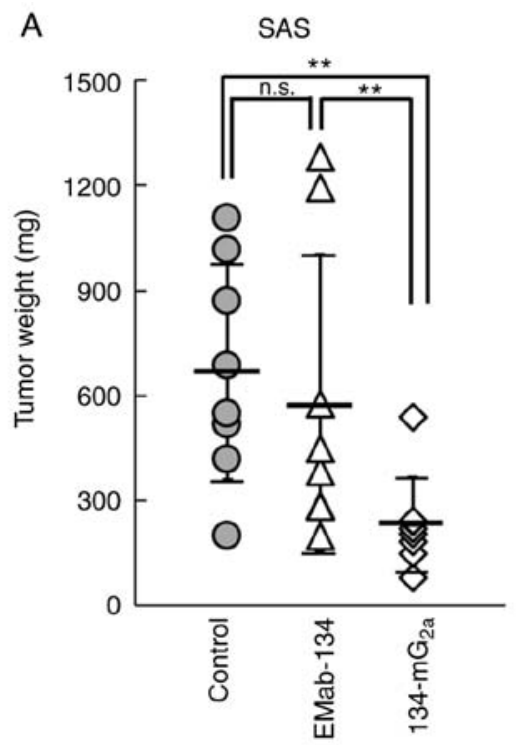

B

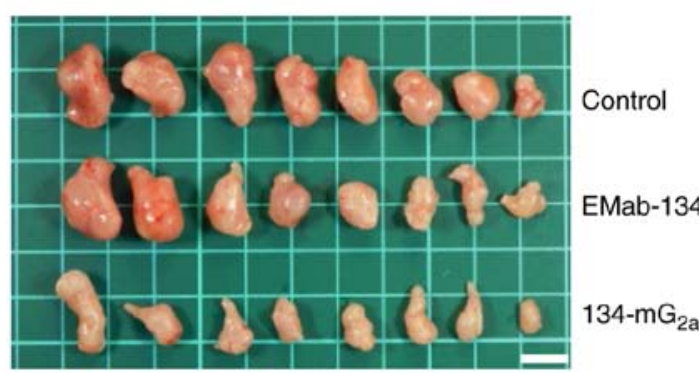

Figure 12. Evaluation of antitumor activity of $134-\mathrm{mG}_{2 \mathrm{a}}$ in SAS xenografts (tumor weight). (A) Xenograft tumors were resected from each mouse on day 18 ; tumor weights were determined. Values shown are the means \pm SEM. Asterisks indicate statistical significance $\left({ }^{* *} \mathrm{P}<0.01\right.$; n.s., not significant; one-way ANOVA and Tukey-Kramer's test). (B) Resected tumors of SAS xenografts from each group on day 18 . Scale bar, $1 \mathrm{~cm}$.

when compared to tumors from the EMab-134-treated mice (Fig. 11). No significant differences between EMab-134 and 
control mouse IgG-treated mice on days 7, 9, 14 and 18 were observed. The administration of $134-\mathrm{mG}_{2 \mathrm{a}}$ resulted in a $70 \%$ reduction in tumor volume on day 18 compared to the responses observed among the EMab-134-treated mice. Tumors from the $134-\mathrm{mG}_{2 \mathrm{a}}$-treated mice weighed significantly less than the tumors from the EMab-134-treated mice $(60 \%$ reduction; $\mathrm{P}<0.01$, Fig. 12A). No significant differences in tumor weight were observed when comparing the tumors from the EMab-134and control mouse IgG-treated mouse resected on day 18 . The tumors resected from the mice are shown in Fig. 12B. Total body weights did not significantly differ among the three groups (data not shown). These results indicated that the administration of 134- $\mathrm{mG}_{2 \mathrm{a}}$ effectively limited the growth of SAS xenografts.

\section{Discussion}

The authors of the present study previously established a sensitive and specific anti-EGFR mAb, EMab-134 (mouse $\mathrm{IgG}_{1}$ ), which is very useful for several applications, including flow cytometry, western blot analysis and immunohistochemistry (14). This antibody could not be used to investigate antitumor activity as the $\operatorname{IgG}_{1}$ subclass does not exhibit ADCC/CDC activities. Therefore, EMab-134 was converted into $134-\mathrm{mG}_{2 \mathrm{a}}\left(\mathrm{IgG}_{2 \mathrm{a}}\right.$ subclass). It was demonstrated that 134- $\mathrm{mG}_{2 \mathrm{a}}$ elicits both ADCC and CDC in vitro (Figs. 5 and 6), and antitumor activities against both $\mathrm{CHO} / \mathrm{EGFR}$ xenografts (Figs. 7 and 8) and OSCC xenografts (Figs. 9-12) in vivo. Importantly, the administration of $134-\mathrm{mG}_{2 \mathrm{a}}$ efficiently reduced the growth of OSCC xenografts at all time points examined when compared to the responses to EMab-134. Nevertheless, only limited reductions in HSC-2 and SAS tumor volume were observed in response to the administration of $134-\mathrm{mG}_{2 \mathrm{a}}$, to 57 and $70 \%$, respectively. These results suggest that targeting EGFR with this antibody may not be sufficient to eliminate most OSCCs. The authors have previously added EGF to HSC-2 and SAS cell lines; however, these cell lines did not respond to EGF stimulation and did not grow well compared to the control cells (21). The results indicated that $134-\mathrm{mG}_{2 \mathrm{a}}$ and EMab-134 antibodies could not neutralize the EGF-EGFR axis. Taken together, antitumor activities by $134-\mathrm{mG}_{2 \mathrm{a}}$ were exerted by ADCC and CDC activities, not neutralization.

In a previous study, it was found that HER2 was expressed in oral cancers, and that the administration of an anti-HER2 mAb (clone $\mathrm{H}_{2} \mathrm{Mab}-19$, mouse $\mathrm{IgG}_{2 \mathrm{~b}}$ ) resulted in antitumor activity against HSC-2 and SAS xenografts (23). By contrast, Mirza et al (24) demonstrated that only one case out of 140 OSCCs was HER2-positive; as such, the feasibility of anti-HER2 therapy for OSCC remains uncertain. In another study, the authors developed a sensitive and specific $\mathrm{mAb}$ against EGFR that recognized a distinct epitope (clone EMab-17, mouse $\operatorname{IgG}_{2 \mathrm{a}}$ ) and that elicited both ADCC and $\mathrm{CDC}$, as well as antitumor activity against HSC-2 and SAS xenografts (21). The extent of ADCC, CDC or antitumor activities of EMab-17 and 134- $\mathrm{mG}_{2 \mathrm{a}}$ were not yet compared, nor was the binding epitope of EMab-17 determined; further investigations are warranted in order to select the optimal anti-EGFR $\mathrm{mAb}$ for the treatment of OSCCs.

The authors previously converted an anti-podocalyxin (PODXL) $\mathrm{mAb}_{\mathrm{Ab}} \mathrm{IgG}_{1}$ subclass (PcMab-47) into a mouse $\mathrm{IgG}_{2 \mathrm{a}}$-type $\mathrm{mAb}\left(47-\mathrm{mG}_{2 \mathrm{a}}\right)$ to facilitate the evaluation of ADCC and CDC (25). The authors also developed $47-\mathrm{mG}_{2 \mathrm{a}}-\mathrm{f}$, a core fucose-deficient variant of $47-\mathrm{mG}_{2 \mathrm{a}}$ in order to increase its ADCC. In vivo analysis revealed that $47-\mathrm{mG}_{2 \mathrm{a}}-\mathrm{f}$, but not $47-\mathrm{mG}_{2 \mathrm{a}}$, exerted antitumor activity in HSC-2 and SAS xenograft models at administered 3 times at doses of $100 \mu \mathrm{g} / \mathrm{mouse} /$ week; these results indicated that a core fucose-deficient anti-PODXL mAb may also be useful for antibody-based therapy against PODXL-expressing OSCCs. Moreover, a cancer-specific mAb (CasMab) against podoplanin (PDPN) was established, which is expressed in a number of types of cancer, including oral cancers (26). In xenograft models of HSC-2 cells, a mouse-human chimeric mAb, chLpMab-23, exerted antitumor activity by engaging human NK cells; these results suggest that chLpMab-23 may be advantageous for antibody therapy against PDPN-expressing oral cancers (27). Antibody regimens that focus on multiple targets, including EGFR, HER2, PODXL and PDPN, may ultimately be effective with the goal of conquering oral cancers. In the future, cancer-specific anti-EGFR mAbs may also be developed that can reduce the adverse effects of traditional antibody therapy.

\section{Acknowledgements}

The authors would like to thank Ms. Saori Handa, Ms. Saki Okamoto and Mr. Yu Komatsu (Department of Antibody Drug Development, Tohoku University Graduate School of Medicine) for providing technical assistance with the in vitro experiments, and Ms. Akiko Harakawa (Institute of Microbial Chemistry (BIKAKEN), Numazu, Microbial Chemistry Research Foundation) for providing technical assistance with the animal experiments.

\section{Funding}

The present study was supported in part by the Japan Agency for Medical Research and Development (AMED) under the grant nos. JP20am0401013 (to YK), JP20am0101078 (to YK) and JP20ae0101028 (to YK), and by the Japan Society for the Promotion of Science (JSPS) Grants-in-Aid for Scientific Research (KAKENHI) grant no. 17K07299 (to MKK), grant no. 19K07705 (to YK), and grant no. 20K16322 (to MS).

\section{Availability of data and materials}

The datasets used and/or analyzed during the study are available from the corresponding author on reasonable request.

\section{Authors' contributions}

HHo, TO, JT, TN, MS TA, YS and MY performed the experiments. MKK analyzed the experimental data. MK, HHa and YK conceived and designed the present study and wrote the manuscript. All authors read and approved the final manuscript.

\section{Ethics approval and consent to participate}

Animal experiments for ADCC and the antitumor activity were approved by the institutional committee for experiments 
of the Institute of Microbial Chemistry (Permit. no. 2019-049 for ADCC assays, 2019-046 for antitumor experiments). The tissues used were from a purchased tissue microarray.

\section{Patient consent for publication}

Not applicable.

\section{Competing interests}

The authors declare that they have no competing interests.

\section{References}

1. Bray F, Ferlay J, Soerjomataram I, Siegel RL, Torre LA and Jemal A: Global cancer statistics 2018: GLOBOCAN estimates of incidence and mortality worldwide for 36 cancers in 185 countries. CA Cancer J Clin 68: 394-424, 2018.

2. Rivera C: Essentials of oral cancer. Int J Clin Exp Pathol 8: 11884-11894, 2015.

3. Guneri $\mathrm{P}$ and Epstein JB: Late stage diagnosis of oral cancer: Components and possible solutions. Oral Oncol 50: 1131-1136, 2014.

4. Vokes EE: Induction chemotherapy for head and neck cancer: Recent data. Oncologist 15: 3-7, 2010.

5. Marcazzan S, Varoni EM, Blanco E, Lodi G and Ferrari M: Nanomedicine, an emerging therapeutic strategy for oral cancer therapy. Oral Oncol 76: 1-7, 2018.

6. Furness S, Glenny AM, Worthington HV, Pavitt S, Oliver R, Clarkson JE, Macluskey M, Chan KK and Conway DI: Interventions for the treatment of oral cavity and oropharyngeal cancer: Chemotherapy. Cochrane Database Syst Rev 13: CD006386, 2011.

7. Dokala A and Thakur SS: Extracellular region of epidermal growth factor receptor: A potential target for anti-EGFR drug discovery. Oncogene 36: 2337-2344, 2017.

8. Ogiso H, Ishitani R, Nureki O, Fukai S, Yamanaka M, Kim JH, Saito K, Sakamoto A, Inoue M, Shirouzu M and Yokoyama S: Crystal structure of the complex of human epidermal growth factor and receptor extracellular domains. Cell 110: 775-787, 2002.

9. Downward J, Yarden Y, Mayes E, Scrace G, Totty N, Stockwell P, Ullrich A, Schlessinger J and Waterfield MD: Close similarity of epidermal growth factor receptor and v-erb-B oncogene protein sequences. Nature 307: 521-527, 1984.

10. Mendelsohn J: The epidermal growth factor receptor as a target for cancer therapy. Endocr Relat Cancer 8: 3-9, 2001.

11. Schultheis B, Reuter D, Ebert MP, Siveke J, Kerkhoff A, Berdel WE, Hofheinz R, Behringer DM, Schmidt WE, Goker E, et al: Gemcitabine combined with the monoclonal antibody nimotuzumab is an active first-line regimen in KRAS wildtype patients with locally advanced or metastatic pancreatic cancer: A multicenter, randomized phase IIb study. Ann Oncol 28: 2429-2435, 2017.

12. Cohen RB: Current challenges and clinical investigations of epidermal growth factor receptor (EGFR)- and ErbB family-targeted agents in the treatment of head and neck squamous cell carcinoma (HNSCC). Cancer Treat Rev 40: 567-577, 2014.

13. Ma H, Jin S, Yang W, Zhou G, Zhao M, Fang S, Zhang Z and $\mathrm{Hu} \mathrm{J}$ : Interferon-alpha enhances the antitumour activity of EGFR-targeted therapies by upregulating RIG-I in head and neck squamous cell carcinoma. Br J Cancer 118: 509-521, 2018.

14. Itai S, Yamada S, Kaneko MK, Chang YW, Harada H and Kato Y: Establishment of EMab-134, a sensitive and specific anti-epidermal growth factor receptor monoclonal antibody for detecting squamous cell carcinoma cells of the oral cavity. Monoclon Antib Immunodiagn Immunother 36: 272-281, 2017.
15. Kaneko MK, Yamada S, Itai S, Chang YW, Nakamura T, Yanaka $M$ and Kato Y: Elucidation of the critical epitope of an anti-EGFR monoclonal antibody EMab-134. Biochem Biophys Rep 14: 54-57, 2018

16. Itai S, Kaneko MK, Fujii Y, Yamada S, Nakamura T, Yanaka M, Saidoh N, Handa S, Chang YW, Suzuki H, et al: Development of EMab-51, a sensitive and specific anti-epidermal growth factor receptor monoclonal antibody in flow cytometry, western blot, and immunohistochemistry. Monoclon Antib Immunodiagn Immunother 36: 214-219, 2017.

17. Fujii Y, Kaneko M, Neyazaki M, Nogi T, Kato Y and Takagi J: PA tag: A versatile protein tagging system using a super high affinity antibody against a dodecapeptide derived from human podoplanin. Protein Expr Purif 95: 240-247, 2014.

18. Fujii Y, Kaneko MK, Ogasawara S, Yamada S, Yanaka M, Nakamura T, Saidoh N, Yoshida K, Honma R and Kato Y: Development of RAP tag, a novel tagging system for protein detection and purification. Monoclon Antib Immunodiagn Immunother 36: 68-71, 2017.

19. Fujii Y, Kaneko MK and Kato Y: MAP Tag: A novel tagging system for protein purification and detection. Monoclon Antib Immunodiagn Immunother 35: 293-299, 2016.

20. Kawada M, Inoue H, Kajikawa M, Sugiura M, Sakamoto S, Urano S, Karasawa C, Usami I, Futakuchi M and Masuda T: A novel monoclonal antibody targeting coxsackie virus and adenovirus receptor inhibits tumor growth in vivo. Sci Rep 7: 40400, 2017.

21. Takei J, Kaneko MK, Ohishi T, Kawada M, Harada $\mathrm{H}$ and Kato Y: A novel anti-EGFR monoclonal antibody (EMab-17) exerts antitumor activity against oral squamous cell carcinomas via antibody-dependent cellular cytotoxicity and complement-dependent cytotoxicity. Oncol Lett 19: 2809-2816, 2020.

22. Kato Y, Kunita A, Fukayama M, Abe S, Nishioka Y, Uchida H, Tahara H, Yamada S, Yanaka M, Nakamura T, et al: Antiglycopeptide mouse monoclonal antibody LpMab-21 exerts antitumor activity against human podoplanin through antibody-dependent cellular cy totoxicity and complement-dependent cytotoxicity. Monoclon Antib Immunodiagn Immunother 36: 20-24, 2017.

23. Takei J, Kaneko MK, Ohishi T, Kawada M, Harada H and Kato Y: H2Mab-19, an anti-human epidermal growth factor receptor 2 monoclonal antibody exerts antitumor activity in mouse oral cancer xenografts. Exp Ther Med 20: 846-853, 2020.

24. Mirza S, Hadi N, Pervaiz S, Khan SZ, Mokeem SA, Abduljabbar T, Al-Hamoudi N and Vohra F: Expression of HER-2/neu in oral squamous cell carcinoma. Asian Pac J Cancer Prev 21: 1465-1470, 2020.

25. Itai S, Ohishi T, Kaneko MK, Yamada S, Abe S, Nakamura T, Yanaka M, Chang YW, Ohba SI and Nishioka Y: Anti-podocalyxin antibody exerts antitumor effects via antibody-dependent cellular cytotoxicity in mouse xenograft models of oral squamous cell carcinoma. Oncotarget 9: 22480-22497, 2018.

26. Kato Y and Kaneko MK: A cancer-specific monoclonal antibody recognizes the aberrantly glycosylated podoplanin. Sci Rep 4: 5924,2014

27. Kaneko MK, Nakamura T, Kunita A, Fukayama M, Abe S, Nishioka Y, Yamada S, Yanaka M, Saidoh N, Yoshida K, et al: ChLpMab-23: Cancer-specific human-mouse chimeric anti-podoplanin antibody exhibits antitumor activity via antibody-dependent cellular cytotoxicity. Monoclon Antib Immunodiagn Immunother 36: 104-112, 2017.

This work is licensed under a Creative Commons Attribution-NonCommercial-NoDerivatives 4.0 International (CC BY-NC-ND 4.0) License. 